\title{
Strategi Komunikasi Forum Kerukunan Umat Beragama dalam Pembinaan Kerukunan Umat Lintas Agama di Kabupaten Mojokerto
}

\author{
G.A.A Agustine Dwi Pradnyaningrat ${ }^{1}$, I Gusti Ngurah Sudiana², Putu Kussa Laksana Utama ${ }^{3}$ \\ ${ }^{2}$ Program Studi Pascasarjana, ${ }^{13}$ Program Studi Komunikasi Hindu \\ Fakultas Dharma Duta, Institut Hindu Dharma Negeri Denpasar
}

\begin{abstract}
This research is mainly discussing about the FKUB in Mojokerto Regency where many cross-religion disputes occur. Based on that fact, the problems discussed in this reserach are (1) How is the eksistence of FKUB playing a role in maintaining the cross-religion harmony in Mojokerto? (2) What is the impact given by the FKUB in maintaining the cross-religion harmony in Mojokerto? (3) What is the benefit of communication strategy developed by FKUB in maintaining the cross-religion harmony in Mojokerto?

The theories used in this reasearc are (1) the theory of existence by Soren Kierkegaard, (2) the theory of structural fungsional, (3) constructivist theory. This research is using several methods which are Qualitative method with phenomenological approach. The location of this research is Mojokerto Regency while the data used is qualitative data. The data source are primary and secondary data. The technique to determine the informan is purvosive sampling.

This research found that (1) The existence of FKUB in carried out dialog between the leaders of various religions create a guideline for each religion to create peace and harmony among them selves and with others. (2) The positive impact is the harmony between religion exist but the negative effect is the bad impression while making the majority as decision maker. (3) there are three benefits gained from the comunication strategy of FKUB which are the villagers become more harmonious especially those having various religions, for the local organization, its member can blend in without thinking about their differences and third for the government officers where they can do their duty without thinking about their differences. It can be said that FKUB is doing an excellent job.

Keywords communication strategy, Religions Harmony Forum and harmony among cross-religions people.
\end{abstract}

\footnotetext{
${ }^{1}$ gustiagungayu20.09@gmail.com

2 Igusti_ngurahsudiana@ihdn.ac.id

${ }^{3}$ kussa_laksana@ihdn.ac.id
} 


\section{PENDAHULUAN}

Indonesia merupakan negara yang majemuk, dari segi sosial, budaya, ekonomi, politik, maupun agamanya. Indonesia memiliki wilayah yang terdiri dari sejumlah pulau. Setiap pulau dan daerah tentu memiliki adat istiadat dan ciri khasnya tersendiri. Kemerdekaan Indonesia wajib diisi dengan kebijakan dan usaha-usaha agar terciptanya tujuan bersama serta tujuan nasional yang tercantum dalam pembukaan UUD 1945 yaitu "Melindungi segenap bangsa Indonesia dan seluruh tumpah darah Indonesia dan untuk memajukan kesejahteraan umum, mencerdaskan kehidupan bangsa dan ikut melaksanakan ketertiban dunia yang berdasarkan kemerdekaan, perdamaian abadi dan keadilan sosial".

Kesadaran akan pentingnya kerukunan hidup beragama di tubuh bangsa Indonesia karena secara historis agama-agama Hindu-Budha, Katolik-Protestan dan Islam telah menjadi agama pribumi di tanah air ini. Artinya keberadaan agama-agama ini bukan baru berjumpa atau baru saling kenal, tapi sudah lama hidup bergaul bersama sebagai satu bangsa, berbicara dalam satu bahasa dan hidup di dalam satu tanah air, Indonesia. Kedudukan dan penilaian nasional yang diberikan kepada agama tersebut berdasarkan Pancasila dan Undang-Undang Dasar 1945 adalah sama. Kesadaran dari sudut ajaran agama mengajarkan toleransi, solidaritas, kebebasan kedamaian dan sebagainya (SK Menteri Dalam Negeri, 2011,
Keputusan Bersama Menteri Agama).

Kerukunan dalam toleransi umat beragama yakni kerukunan yang dinamis dan saling terbuka. Kerukunan perlu adanya suasana yang harmonis, saling kerjasama dan saling tolong menolong. Apabila belum bisa saling bekerjasama, hendaknya jangan saling mengganggu dengan yang lain dalam agama. Kerukunan sesama umat beragama lebih mudah dibangun karena keyakinan yang sama, namun tidak menutup kemungkinan di dalamnya tidak terjadi konflik. Akan tetapi, kerukunan antar umat beragama lebih sulit dibangun karena perbedaan keyakinan yang mendasar contoh, konflik yang terjadi kerukunan antar umat beragama yaitu pada pendirian rumah ibadah di desa Temon Kecamatan Trowulan Kabupaten Mojokerto karena disebabkan oleh kesalahpahaman. Pemerintah dan masyarakat telah membangun suatu lembaga kerukunan antar umat beragama yang bisa menjadi jembatan penyelesaian konflik agama yaitu Forum Kerukunan Umat Beragama (FKUB).

Kabupaten Mojokerto termasuk salah satu kabupaten yang sudah menggunakan organisasi FKUB sebagai jembatan adanya kerukunan antar umat beragama pada masyarakatnya. Kabupaten Mojokerto merupakan pemeluk yang taat pada agamanya masing-masing, tetapi disisi lain mereka yang paham mayoritas masih melarang pendirian rumah ibadah umat lain dikarenakan dengan suatu alasan tertentu misalnya memanipulasi tanda tangan mereka untuk pendirian rumah ibadah. FKUB sangat berperan penting dalam hal kerukunan umat beragama di Kabupaten Mojokerto, karena FKUB 
merupakan jembatan untuk berdialog dan melakukan pembinaan umat lintas agama agar tercipta kerukunan dan tidak adanya lagi kesalahpahaman dalam pendirian rumah ibadah paham minoritas.

Maka dari itu toleransi antar umat lintas agama sangat perlu untuk hidup saling menghormati, saling menghargai dan saling tolong menolong bagi masyarakat Kabupaten Mojokerto. Agama yang ada dan berkembang di kabupaten Mojokerto ada enam yaitu; Islam, Kristen, Katholik, Hindu, Buddha dan Konghuchu. Salah satu contoh pendirian rumah ibadah di desa Temon, Kecamatan Trowulan Kabupaten Mojokerto ini masih kurang disetujui warga karena tidak ada pemberitahuan ke warga setempat bahwa akan didirikannya Pura, tidak ada pemberitahuan ke PHDI (Parisadha Hindu Dharma Indonesia) serta lembaga terkait di Kabupaten Mojokerto seperti Kementerian Agama dan FKUB di Kabupaten Mojokerto, oleh karenanya peneliti tertarik untuk mengkaji lebih lanjut persoalan tersebut dalam bentuk skripsi dengan judul "Strategi Komunikasi Forum Kerukunan Umat Beragama dalam Pembinaan Umat Lintas Agama di Kabupaten Mojokerto".

Menanggapi berbagai konflik yang ada di Indonesia termasuk kesalahpahaman pendirian rumah ibadah umat Hindu (Pura) serta umat Kristen (Gereja) yang mana terkait kerukunan umat beragama, maka sesuai Peraturan Bersama Menteri Agama dan Menteri Dalam Negeri Nomor 9 dan 8 Tahun 2006, tentang pembentukan Forum Kerukunan Umat Beragama di tingkat provinsi dan kabupaten/kota dibentuklah FKUB Kab.Mojokerto yang berdiri berdasarkan SK Bupati Mojokerto
Nomor 188.45/279/HK/416-012/2015, tanggal 20 Februari 2015 dan Peraturan Bersama Menteri Agama dan Menteri Dalam Negeri Nomor 9 Dan Nomor 8 Tahun 2006.

Adapun ketertarikan peneliti untuk mengangkat judul tersebut yakni: 1. Adanya kesalahpahaman dalam ijin pembangunan tempat ibadah umat Hindu (Pura), tempat ibadah umat Kristen (Gereja) 2. Adanya kesalahpahaman dalam pemakaman umat Kristen yang dimakamkan di kuburan umat Islam 3. Meningkatkan peran dan fungsi lembaga keagamaan yang bersifat sosial dengan umat beragama lainnya 4. Ikut mengatasi dampak perubahan yang terjadi dalam aspek kehidupan untuk memperkukuh jati diri dan kepribadian, serta memperkuat kerukunan hidup bermasyarakat.

\section{PEMBAHASAN}

Lokasi penelitian ini adalah Kabupaten Mojokerto, ini karena FKUB berada di kabupaten ini. Alasan memilih lokasi penelitian ini dikarenakan masih adanya kesalahpahaman dalam ijin pembangunan tempat ibadah umat Hindu (Pura) dan adanya kesalahpahaman dalam pemakaman umat Kristen di kuburan Islam yang sampai saat ini perlu dikembangkan keterbukaannya serta kerukunannya. Sehingga, peneliti dapat mengetahui strategi yang digunakan FKUB dalam melakukan pembinaan kerukunan umat lintas agama di wilayahnya dan memutuskan untuk memilih Kabupaten Mojokerto sebagai tempat penelitian. Untuk itu sekiranya lokasi penelitian ini dapat digunakan objek penelitian yang sangat menarik. 
Eksistensi FKUB dalam pembinaan kerukunan umat lintas agama dapat dijelaskan mulai dari sejarah berdirinya FKUB yang berdasarkan terbitnya SK Bupati Mojokerto Nomor 188.45/279/HK/416-012/2015, tanggal 20 Februari 2015 serta peraturan bersama menteri agama dan menteri dalam negeri nomor 9 dan 8 Tahun 2006, tentang pembentukan Forum Kerukunan Umat Beragama di tingkat provinsi dan kabupaten/kota. Peraturan ini yang menjadi dasar dan cikal bakal berdirinya FKUB. Adapun dalam pembentukan FKUB Kabupaten Mojokerto didahului dengan adanya musyawarah bersama dihadiri oleh perwakilan-perwakilan dari masing-masing pemuka agama, yaitu: dari umat Islam yang diwakili oleh Majelis Ulama Indonesia, dari umat Katolik yang diwakili oleh Konferensi Wali Gereja Indonesia, dari umat Kristen yang diwakili oleh Persekutuan GerejaGereja Indonesia, dari umat Hindu yang diwakili oleh Parisada Hindu Dharma Indonesia, dari umat Buddha yang diwakili oleh Wali Umat Buddha Indonesia, dari umat Konghuchu yang diwakili oleh Majelis Tinggi Agama Konghuchu dan dari Kementrian Agama yang diwakili oleh Kandepag Kabupaten Mojokerto dan Wakil Bupati. Mekanisme Kerja FKUB Kabupaten Mojokerto terbagi menjadi beberapa tahap yaitu: rapat harian, dalam rapat ini membahas mengenai program-program kerja yang akan dilaksanakan dan serta evaluasi mengenai program kerja yang telah dilaksanakan. Rapat pleno, dalam rapat ini membahas tentang peraturan perundang-undangan daerah serta peraturan yang akan disosialisasikan kepada masyarakat. Berbagai kegiatan sosialisasi dan dialog antar pemuka agama yang telah diselenggarakan oleh
FKUB agar dapat menjaga kurukunan antarumat beragama.

FKUB diciptakan untuk mempermudah menjaga kerukunan antar umat lintas agama. Namun, FKUB juga membawa dampak bagi masyarakat tergantung dari penyampaian strategi komunikasi oleh organisasi tersebut. Dampak merupakan perubahan yang terjadi pada individu atau sistem sosial, akibat dari penerimaan atau penolakan sebuah inovasi (Nurudin, 2017: 103). Penggunaan strategi komunikasi pada FKUB memiliki dampak positif dan dampak negatif, hal tersebut dikarenakan masing-masing masyarakat memiliki prespektif pandang yang berbeda-beda. Dapat disimpulkan bahwa dampak positif dari strategi komunikasi yang digunakan FKUB yakni ketika ada kegiatan lintas agama di salah satu desa di kecamatan Mojosari dan lebih mengenal, berbagi ilmu dan berteman tanpa adanya perbedaan. Dan dampak negatif dari strategi komunikasi yang digunakan yakni masih adanya istilah "Asu Gede Menang Kerahe" yang menimbulkan kecemburuan sosial dalam berpendapat dan mengambil keputusan. Manfaat strategi komunikasi FKUB dibagi menjadi tiga yakni: bagi masyarakat, bagi organisasi, bagi pemerintah. Bagi masyarakat strategi komunikasi yang dijalankan FKUB memberi manfaat terbukanya pemikiran dan saling toleransi. Bagi organisasi strategi komunikasi yang dijalankan FKUB memberi manfaat terjadi interaksi antar organisasi umat beragama sehingga komunikasi yang positif, terjadi kerukunan dan bisa mempererat persaudaraan antar pemuda umat beragama yang ada di kabupaten Mojokerto. Bagi pemerintah strategi komunikasi yang dijalankan FKUB 
memberi manfaat terselesaikannya masalah antar umat beragama yang terjadi di Mojokerto.

\section{SIMPULAN}

Berdasarkan penyajian data dan analisis data pada maka dapat disimpulkan sebagai berikut: (1) Eksistensi Forum Kerukunan Umat Beragama dalam pembinaan kerukunan umat lintas agama di kabupaten Mojokerto tercermin dalam proses pembentukannya, tugas penguruspengurusnya, mekanisme kerja FKUB Mojokerto, konflik yang pernah terjadi, serta posisi FKUB sendiri dalam masyarakat Mojokerto (2) Strategi komunikasi yang digunakan FKUB Kab.Mojokerto dalam melakukan pembinaan umat membawa dampak yang positif dan negatif (3) Strategi komunikasi FKUB Kab.Mojokerto dalam melakukan pembinaan memberi manfaat bagi masyarakat, organisasi, dan pemerintah.

Berdasarkan simpulan tersebut, penulis dapat menyarankan: (1) Kepada masyarakat kabupaten Mojokerto sebagai umat beragama diharapkan agar mampu mempertahankan dan tidak menganggap perbedaan agama sebagai permasalahan (2) Bagi Organisasi Pemuda Organisasi terkait diharapkan mampu membina kaum generasi muda di jaman sekarang agar tidak adanya percikan kecil dari konflik yang mengatas namakan agama. Ikut serta membantu FKUB dalam membina kerukunan umat lintas agama di Kabupaten Mojokerto agar terciptanya Mojokerto yang damai dan bebas dari konflik lintas agama (3) Bagi Forum Kerukunan Umat Beragama diharapkan agar mengajak serta menghimbau kaum generasi muda agar meningkatkan sikap toleransi lintas agama sehingga tidak terjadinya perpecahan yang akan menjadi besar. Menggerakkan anti hoax dan memerangi berita-berita hoax pada kaum generasi muda yang mudah tersulut api amarahnya karena kurangnya pengetahuan tentang berita hoax (4) Bagi pemerintah kabupaten Mojokerto diharapkan memfasilitasi serta selalu mendukung kegiatan yang bertemakan kerukunan lintas agama agar masyarakat paham akan indahnya keberagaman suku, agama dan adat istiadat yang berbeda di Indonesia khususnya di Mojokerto dan dalam rangka mempertahankan kerukunan antar umat beragama di kabupaten Mojokerto, agar lebih memperhatikan keberadaan FKUB sebagai lembaga yang menjaga kerukunan antar umat beragama milik pemerintah yang perlu dipertahankan (5) Bagi peneliti lain diharapkan dapat lebih menggali mengenai strategi komunikasi FKUB dalam pembinaan kerukunan umat lintas agama secara spesifik dan mendalam. Sehingga peneliti selanjutnya dapat lebih baik dari peneliti yang sekarang. Hasil penelitian ini diharapkan dapat menjadi bahan rujukan bagi peneliti selanjutnya.

\section{DAFTAR PUSTAKA}

Nurudin. 2017. Ilmu Komunikasi IImiah dan Populer. Jakarta : Rajawali Pers 